\title{
Inca human sacrifices from the Ampato and Pichu Pichu volcanoes, Peru: new results from a bio-anthropological analysis
}

\author{
Dagmara M. Socha ${ }^{1}$ (D) - Johan Reinhard ${ }^{2} \cdot$ Ruddy Chávez Perea ${ }^{3}$ \\ Received: 26 October 2020 / Accepted: 29 March 2021 / Published online: 14 May 2021 \\ (C) The Author(s) 2021
}

\begin{abstract}
One of the most important rituals in the Inca Empire was the capacocha. It required the most prestigious sacrificial offering of male and female children and young women who were characterized by their beauty and purity. The aim of this paper is to present the results of a bio-anthropological analysis of the remains of five individuals sacrificed on the summits of Ampato and Pichu Pichu during this ritual. Various methods (bone analysis and radiography) were applied in the investigation due to the diverse states of preservation of the remains. Four individuals were in the same age category: 6-7 years old. The individual Pichu Pichu \#2 was sacrificed at age 3.5 years, which makes him the youngest capacocha sacrifice currently known. Results show proper development of the victims' bodies, the presence of stress markers related to the early childhood period, and, in the case of the Ampato boy, malformation of the cervical vertebrae. The studies of the Pichu Pichu and Ampato sacrifices confirm their widespread origins, privileged position, and high social status. They show that the victims were well-nourished and had proper body growth compared to juveniles from the lower social strata in different cemeteries in the region.
\end{abstract}

Keywords Incas $\cdot$ Capacocha $\cdot$ Ampato $\cdot$ Pichu Pichu $\cdot$ Human sacrifices

\section{Introduction}

The capacocha was the most important sacrificial ritual to be practised in the Inca Empire. Historical and archaeological studies have demonstrated the complex role of this ritual in the religious and socio-economic systems of the state (Reinhard and Ceruti 2010). The Incas implemented ideological control over the lands and people they conquered, and this was supported through religious beliefs and customs (Malpass and Alconini 2010:44-74). The capacocha, according to the requirements of the state, was used to support the religious syncretism of the provinces and to assign prestige to the local authorities.

Dagmara M. Socha

d.socha@uw.edu.pl

1 Centre for Andean Studies, University of Warsaw, Krakowskie Przedmieście 26/28, 00927 Warsaw, Poland

2 National Geographic Society, 1145 17th St. NW, Washington, DC 20036, USA

3 Museo Santuarios Andinos, Universidad Católica de Santa Maria, 04001 Calle la Merced, 110 Arequipa, Peru
The aim of this article is to present the results of a bioanthropological analysis of children sacrificed on the Ampato and Pichu Pichu volcanoes in southern Peru. The burials were discovered during expeditions led by Johan Reinhard and José Antonio Chávez in the 1990s (Reinhard 2006:170-192). The Ampato capacocha burials, found at $5800 \mathrm{~m}$, consisted of three human bodies with accompanying objects made from silver, gold, Spondylus shell, and ceramic. The Pichu Pichu capacocha burials were located just below the summit at an altitude of $5600 \mathrm{~m}$. Here, the Incas constructed an artificial platform that contained two bodies with rich grave goods and one additional burial outside the platform. A bio-anthropological analysis of the human bodies has revealed new data about the significance of the capacocha and the treatment of the children chosen for sacrifice.

\section{The political and sociological meaning of the capacocha}

Capacochas were conducted for several purposes (Besom 2009: 36-39). These can be divided into rituals performed for the royal court and those performed for provincial shrines and local cult places (Cobo 1990 [1623]:111-112; Hernández 
1923 [1622]:34). The former took place in the imperial capital of Cusco and were often related to important events in the emperor's life (Cobo 1990 [1623]:111-112). Other capacocha ceremonies were performed for local huacas: sacred places, shrines, or objects. They were often performed in response to natural catastrophes such as volcanic eruptions, earthquakes, and climate disasters (such as droughts and hailstorms (Cobo 1990[1623] :54, 112, 150-153; Murúa 1946 [1590]:281; Ondegardo 1917 [1571]:193) and to celebrate major construction activities, especially those related to irrigation structures (Hernández 1923 [1622]: 52). Capacochas were also performed annually during the Inti Raymi and Capac Raymi ceremonies (Guaman Poma de Ayala 1980 [1613]). These ceremonies took place in the Temple of the Sun (Coricancha) in Cusco and were also performed for the most important huacas of the provinces (Cieza de León 1959[1553]:151-152; Cobo 1990 [1623]:54-74, 112).

Huacas played an important role in beliefs in the preColumbian Andes. In the highlands, they were often identified with the highest peak. They were the centre of local religious beliefs and supported the ethnic identity of the local groups, often representing their divine ancestor. By performing rituals for the huacas, the Incas established a hierarchy within local groups and managed provincial politics. By making sacrifices, the Incas also emphasized the position of the emperor as the provider of the realm, as he was able to negotiate with the gods. They thus introduced the local huacas into the imperial pantheon and ascribed to them a place in their religious hierarchy.

Prestigious and political reasons caused the Incas to give the capacocha ritual a rank that allowed it to be performed only by the state (Bray et al. 2005). The ritual included the most important goods manufactured and controlled by the Incas. The children and young women chosen for sacrifice were, ideally, to have great beauty and no imperfections, and the females had to be virgins (Ramos Gavilán 1976 [1621]:56). Children could also come from important ayllus (kinship groups) (Cobo 1990 [1623]:112; Ramos Gavilán 1976 [1621]:56), and the females were often selected from acllahuasi (buildings for housing chosen women). There is some controversy with regard to the physical features described in the chronicles. For example, Ramos Gavilán (1976 [1621]):56) mentioned that a young girl was rejected because she had a small mole, which made her imperfect. The results of bio-anthropological studies, however, show that some of the children sacrificed as capacochas had body marks or even suffered from serious diseases. Boys from Llullaillaco and El Plomo had warts on their hands (Reinhard and Ceruti 2010: 106, Quevedo and Durán 1992:198). The Llullaillaco Maiden had indications of the onset of tuberculosis, and the older individual from Misti had deformed legs that may have affected his walking (Corthals et al. 2012; Socha et al. 2020). Furthermore, the boy from El Plomo had suffered a severe elbow injury that had left a scar (Prunes 1957). He was also infected by parasites on the surface of his skin (Pediculus humanus capitis) and in his digestive tract (Entamoeba coli and Trichuris trichiura) (Quevedo and Duran, 1992: 198).

\section{The capacocha in historical and archaeological sources}

The capacocha ceremony was performed at various locations, including Cusco, Pachacamac, and on the Island of the Sun (Ramos Gavilán 1976 [1621]; Guaman Poma de Ayala 1980 [1613]). However, the human sacrifices connected to these rituals were not positively identified until recent times. The first capacocha burial was found at the end of the nineteenth century on the summit of Chachani, Peru (Beorchia 1985:6566). Another two were found on Chañi (1905) and Chuscha (1921) in present-day Argentina at the beginning of the twentieth century (Schobinger 2003; Reinhard and Ceruti 2010:9). Capacocha offerings were also discovered on the Isla de la Plata in modern Ecuador (Dorsey 1901). In 1954, the mummy of an 8-year-old boy was found near the summit of El Plomo (Sanhueza et al. 2005). The burial of a young woman with the remains of ceremonial architecture was discovered on Pichu Pichu in southern Peru in 1963 (Linares 1966). The bodies of two females (9 and 18-20 years old) were discovered during road construction at Cerro Esmeralda in northern Chile in 1976 (Checura 1977), and the body of a 7- to 8-year-old boy was discovered by climbers on Aconcagua in 1985 (Schobinger 2001).

The next discoveries of high-altitude capacocha burials in Peru, Chile, and Argentina were made by Johan Reinhard and his team (Reinhard and Ceruti 2010). He and his climbing companion, Miguel Zarate, found the first frozen Inca female mummy on Ampato in September 1995. After that, from 1995 to 1999, Reinhard and José Antonio Chávez made several expeditions to mountains in Peru and Argentina, which led to the discoveries of further human sacrifices on (or near) the summits of Ampato, Pichu Pichu, Misti, Sara Sara, Quehuar, and Llullaillaco (Reinhard 2006). In total, they found human remains belonging to 20 individuals varying in age from about 3.5 to 15 years old.

The capacocha ritual could be carried out by communities at a local level. A possible example of this behaviour was found in Choquepukio near Cusco (Andrushko et al. 2011: 323-334). Under the floor of the ceremonial building, archaeologists found burial sites of children aged between about 3 and 12 years old. The bodies were accompanied by ceramic artefacts and figurines made from gold, silver, and Spondylus shells. Similar finds were discovered at the site of La Joya, and these were related to the cult of the Coropuna and Solimana mountains in southern Peru (Meinken 2005: 81-90). 
The ways the children intended for capacocha sacrifice distributed throughout the empire are still unclear. After a ceremony in Cusco, they were reportedly sent to the provinces (Molina 1959 [1573]:89). According to the chronicles, some of them would be returned to the place where they had been born (Hernández 1923 [1622]:52). The journey could sometimes take weeks or months, and the younger children were probably carried on litters. The soles of the feet of the El Plomo boy show hyperkeratosis and oedema, indicating that he made at least part of the pilgrimage on foot (Quevedo and Durán 1992:198). Blood was found in his mouth, suggesting that he may have suffered from a pulmonary oedema due to the altitude. Analysis of the boy from Llullaillaco suggested that he might have died before the procession reached the summit (Ceruti 2015: 8). Chroniclers described some of the children as having been killed by a blow to the head, by being buried alive, by having their hearts removed, or by strangulation (Cobo 1990 [1623]:112; Cieza de León 1959[1553]:150; Hernández 1923[1622]: 61-62).

Evidence of human sacrifices has been found among preInca cultures in the Andes. However, the sacrificing of children in state-sponsored ceremonies was a practice associated primarily with the Incas until a mass sacrifice of children was recently found among the Chimu in northern Peru (Prieto et al. 2019). An estimated 137 children, aged 5 to 14 years, were immolated during the years 1400-1450 AD, and several had signs that their hearts had been removed. The sacrifices probably occurred during an El Niño phenomenon that had caused catastrophic flooding. However, the large number of child sacrificial victims far exceeded those known to have been made by the Incas or indeed by any other society in the Americas (Prieto et al. 2019). Some chroniclers (e.g. Acosta 1962[1590]:248) reported that the Incas sacrificed hundreds of children for important events, but no archaeological evidence has been found of this nor have any of the known Inca sacrificial victims been found with their hearts removed. The Chimu sacrifices also lacked the luxury items found in Inca capacocha burials on mountain summits. Nevertheless, the Chimu were conquered by the Incas in the second half of the fifteenth century, and there is evidence of the Chimu having influenced some Inca cultural practices and crafts (e.g. Cieza de León 1959[1553]:328). The possibility exists that this may have also been the case with beliefs relating to Inca child sacrifices, as those found on mountain summits date to the period of Inca expansion out of the Cusco region in the mid-1400s.

Several of the capacocha victims' bodies recovered to date have not shown any signs of physical trauma. This has led to the conclusion that they may have been intoxicated and buried alive or that some other method, like suffocation, was used that did not leave any recognizable traces (Bárcena 1989; Wilson et al. 2013). The boy found at El Plomo, the Llullaillaco children, and the Aconcagua boy show traces of vomiting which could have been due to altitude sickness but which could also have been due to having been intoxicated prior to death. The results of a toxicological analysis reveal the presence of metabolites related to alcohol and the consumption of coca leaves (Wilson et al. 2013). The techniques used in killing the victims may have been chosen specifically so that all blood remained in their bodies in order to be able to provide an intact sacrifice to the gods.

\section{Pichu Pichu and Ampato expeditions}

In local folklore, Pichu Pichu is considered to be a helpful deity (Reinhard 2006: 169). The shepherds make offerings to gain protection and prosperity for themselves and their herds. The Quechua word "pichu" means a peak, and the double use of the word to name the volcano is to emphasize that it has several peaks. The highest of Pichu Pichu's peaks is $5664 \mathrm{~m}$, and it borders the city of Arequipa to the northeast and east along with the volcanoes of Chachani and Misti (Fig. 1).

The first discovery of an Inca sacrifice on Pichu Pichu was made by mountaineers in 1963 (Linares 1966). They found a partially collapsed artificial platform made by the Incas and uncovered a cranium, a mandible, vertebrae ( $\mathrm{C} 1$ and $\mathrm{C} 2)$, a calcaneus, and pottery and metal objects. These were found just below and outside the eastern wall of the platform, and it appeared that the burial itself had shifted downwards, probably as a result of an earthquake. The main part of the platform remained intact (Fig. 2; Reinhard 2006). The material was eventually taken to be stored in the museum of the Universidad Nacional de San Agustin in Arequipa. The 1963 expedition also observed an Inca tambo (way station) located at $4600 \mathrm{~m}$, which was used by the Incas as a place to store supplies and to rest before proceeding to the summit.

Based on the grave goods, the sex of the sacrificed individual first found on Pichu Pichu was believed to be that of a female (Linares 1966). The age was estimated as 16-18 years old based on the partial eruption of the third molars and the

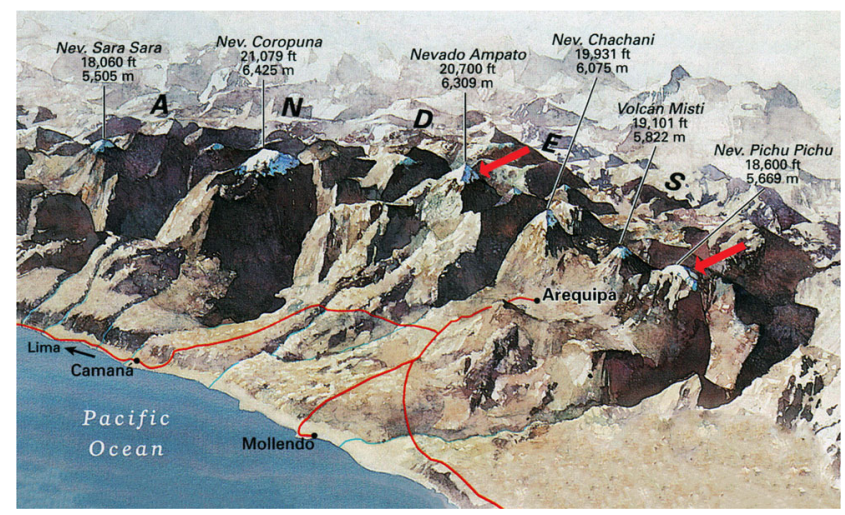

Fig. 1 A map showing volcanoes in southern Peru, with Pichu Pichu and Ampato marked by arrows (courtesy of the National Geographic Society) 


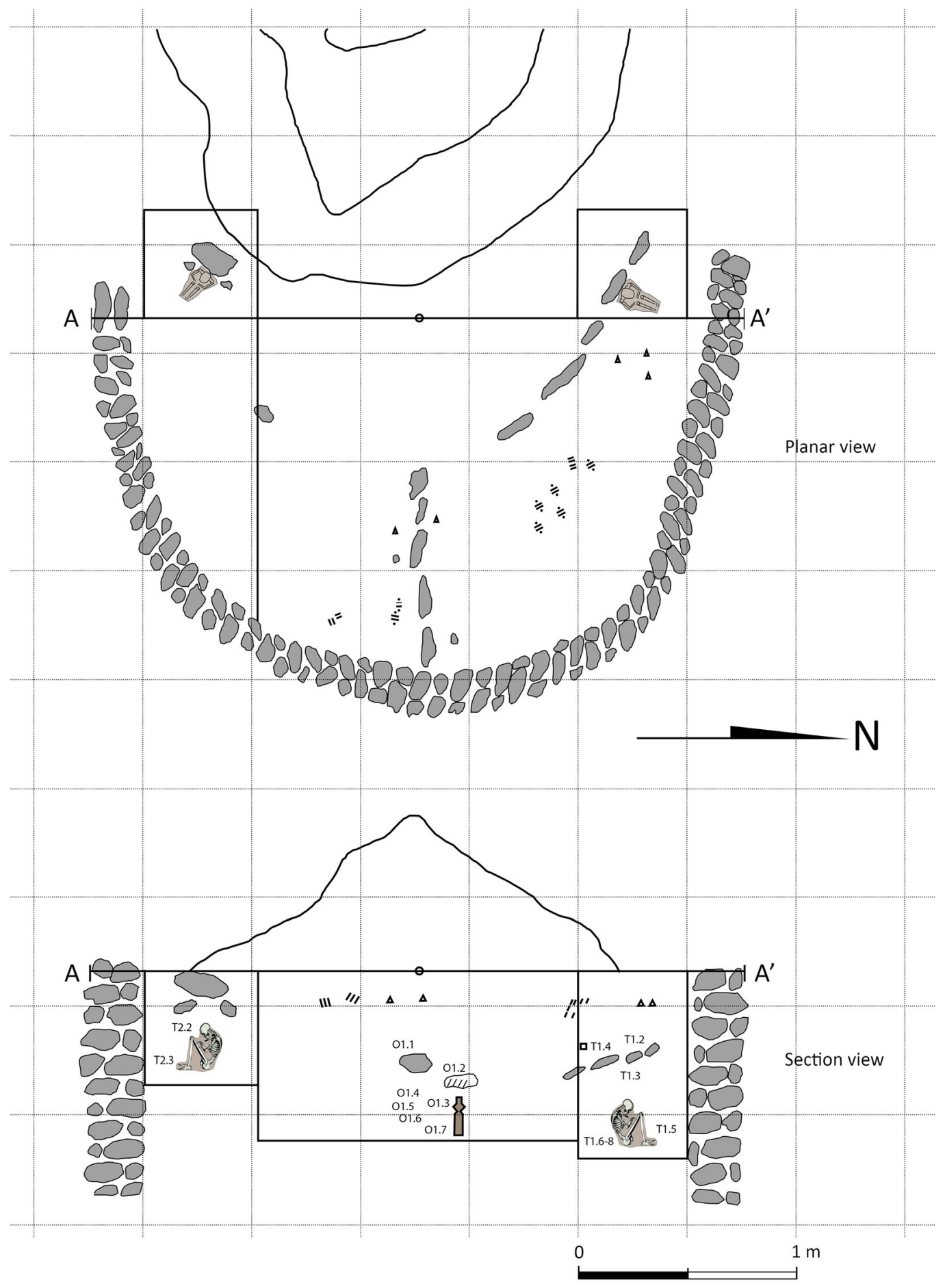

\section{Proyecto Santuries de Altura} del Sur Andino

Pichu- Pichu - $961 \mathrm{C}$

Drawing: \#2

Site: Summit

Location: Platform

Original drawing: J.A.Chávez
Legend:

Iس - textile

$\Delta \mathbf{\Delta}$ - red soil

.II. - pottery

" " - yellow soil

1. figurine
T1.2 Spondylus female statue

T1.3 Silver female statue

T1.4 Gold female statue

T1.5 Silver female statue

T1.6 Gold female statue

T1.7 Silver female statue

T1.8 Spondylus female statue
01.1 Spondylus statue O1.2 Male tunic unku

O1.3 Silver male statue

O1.4 Silver male statue

O1.5 Silver llama figure

O1.6 Spondylus Ilama figure

O1.7 Spondylus Ilama figure

T2.2 Chuspa with coca leaves

T2.3 Spondylus male statue

Fig. 2 The plan of the Inca platform on Pichu Pichu (J. Chávez, J. Stępnik) 
obliteration of the cranial sutures. However, modern studies of the Andean population show that the growth of the teeth starts earlier than in other regions of the world (Gaither 2004), and the stage at which the cranial sutures are obliterated is no longer used in physical anthropology as a valuable diagnostic feature (Meindl and Lovejoy 1985). Due to this, the probable age of the individual should be estimated at 14-17 years old. The cranium had significant damage in the region of the right frontal, parietal, and occipital bones (Linares 1966). A regular shaped polished area was also noticed at the border of the temporal bone. This was interpreted as evidence of trepanation; however, the temporal bone was rarely the area of trepanation because of the presence of hearing organs and main vessels and because it was more complicated to access than the frontal, parietal, or occipital bones (Andrushko and Verano 2008: 10). The damage to the right part of the skull probably occurred perimortem (Linares 1966: 43-44).

Johan Reinhard and José Antonio Chávez led an expedition to Pichu Pichu in 1989 and located the remains of the burial that had been uncovered in 1963 outside of the artificial platform at $5600 \mathrm{~m}$ (Reinhard 2006). Although partially destroyed, the remaining bones of the adult individual (ribs, vertebrae, and long bones) were recovered. The bones were found together with grave goods that included miniature gold and copper tupu pins, two wooden cups, a wooden spoon, beads and pendants for a necklace, and a ball of thread. These finds were deposited in the Museo Nacional de Arqueología y Antropología in Lima.

The 1996 season was focused on excavating the main part of the platform (Reinhard 2006). During this excavation, two new capacocha burials were found. Based on grave goods, one presumably belonged to a female and the other to a male. A gold female figurine was found above the first burial in a box made from small stones, and four more female figurines were located near the individual's body. The second burial was located on the opposite side of the platform. The skeleton of the child (probably male) was accompanied by the carbonized remains of textiles, a bag (chuspa) with coca leaves, and a male figurine. Due to the conditions on the summit, the body of the probable female was excavated with its surrounding soil and transported as a frozen block to Arequipa. During the final days of the 1996 excavation, archaeologists found more offerings, consisting of an unusually large $(30 \mathrm{~cm})$, silver male figure and a male tunic ( $u n k u)$ covered with silver metal discs ${ }^{1}$.

During Inca times, Ampato was mentioned as one of the most important deities in Condesuyos, one of the four parts of the Inca Empire. The volcano is located northwest of the city of Arequipa (Fig. 1). The name of the mountain, Ampato, likely originated from the Quechua word "hampattu" meaning "toad". Frogs and toads often appear in Andean folklore as

\footnotetext{
${ }^{1}$ A similar $u n k u$ was later found with one of the female bodies sacrificed on the volcano of Misti (Socha et al. 2020).
}

they are related to the water cult and witchcraft (Reinhard 2006:12-13; Sikkink 1997: 175; Rescaniere 1986).

Ash from the eruption of Sabancaya in 1990 and 1991 fell on the snow-covered tops of the surrounding mountains, causing them to start melting. This exposed the summit ridge of Ampato (Reinhard 2006). Johan Reinhard and Miguel Zarate examined the summit in September 1995 and discovered the mummy of a 15-year-old girl (later to become known as the "Ampato Maiden") who had been sacrificed on the summit at $6300 \mathrm{~m}$ (Reinhard 2006).

An expedition led by Johan Reinhard and José Antonio Chávez returned to the mountain in October 1995 to systematically search for archaeological sites. They excavated two Inca burials at $5800 \mathrm{~m}$ marked by stone circles and found a probable female mummy and then the skeleton of a possible male individual. The body of the former was well-preserved and wore a headdress made of feathers (Fig. 3). The mummy was found placed on a flat stone inside a burial pit filled with volcanic ash and red soil. Surrounding the mummy were pottery vessels, a wooden box, weaving tools, spoons, two miniature wooden vases (keros), sandals, and two bags (chuspas). The mummy had been struck by lightning while in the burial pit.

The body of the probable male mummy had been significantly destroyed by lightning, and in contrast to the other bodies from Ampato, the soft tissue had been almost completely carbonized (Reinhard and Ceruti 2010: 110). His head was surrounded by a circular headpiece made of vegetal fibre. A gold male figure was located under the pelvis of this individual. Lightning probably directly struck the burial more than once, and the earth from the grave was partly vitrified. The other stone circles did not contain human bodies. However, in one of them, offerings in the form of a large Spondylus shell and of male llama figurines made from silver and Spondylus shell were found.

The archaeologists returned to Ampato summit again in 1996. In the ceremonial area at $5800 \mathrm{~m}$, they found other

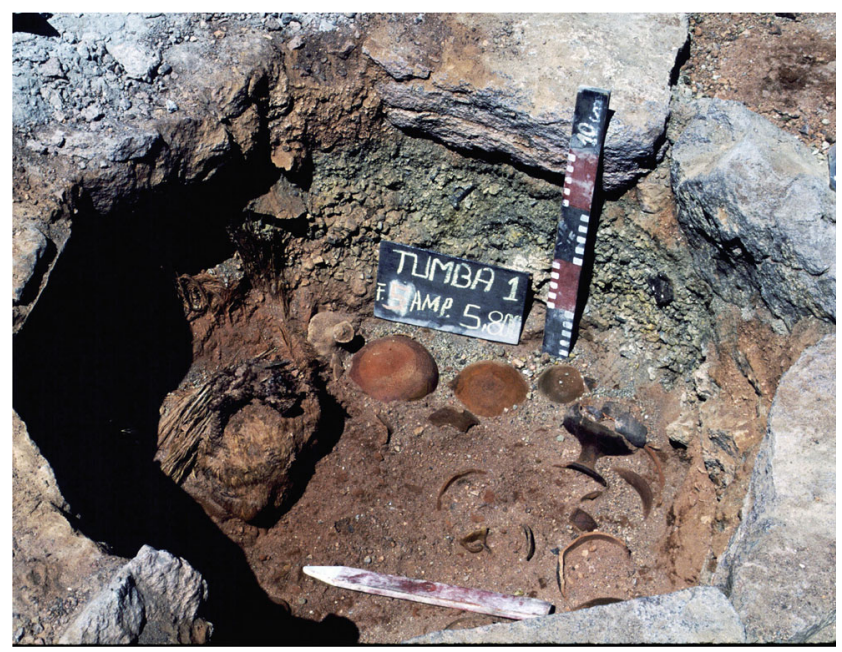

Fig. 3 Ampato \#2's burial during the excavation (photo Johan Reinhard) 
offerings: a blue tunic (unku), a set of red and white woollen cords (with a female Spondylus figurine attached), and two llama figurines. During the last expedition in 1997, the archaeologists found another probably female body at the $5800 \mathrm{~m}$ site (Fig. 4) with a female Spondylus statue next to it. The body was partially mummified; however, the upper part of the mummy bundle was destroyed, and the skull bones were visible.

\section{Material and methods}

Five individuals were the subjects of the present study: Ampato \#2, \#3, and \#4 and Pichu Pichu \#1 and \#2. All of them were found during the expeditions conducted by Johan Reinhard and José Antonio Chávez during the years 19951997. Various methods were used in studying the remains due to the diverse states of preservation of the individuals from Pichu Pichu and Ampato.

Conditions during the excavations of the Pichu Pichu \#2 and Ampato \#3 skeletons were favourable, and this allowed the skeletons to be exhumed at the sites (Reinhard 2006). The body of Pichu Pichu \#1 was found completely frozen. The

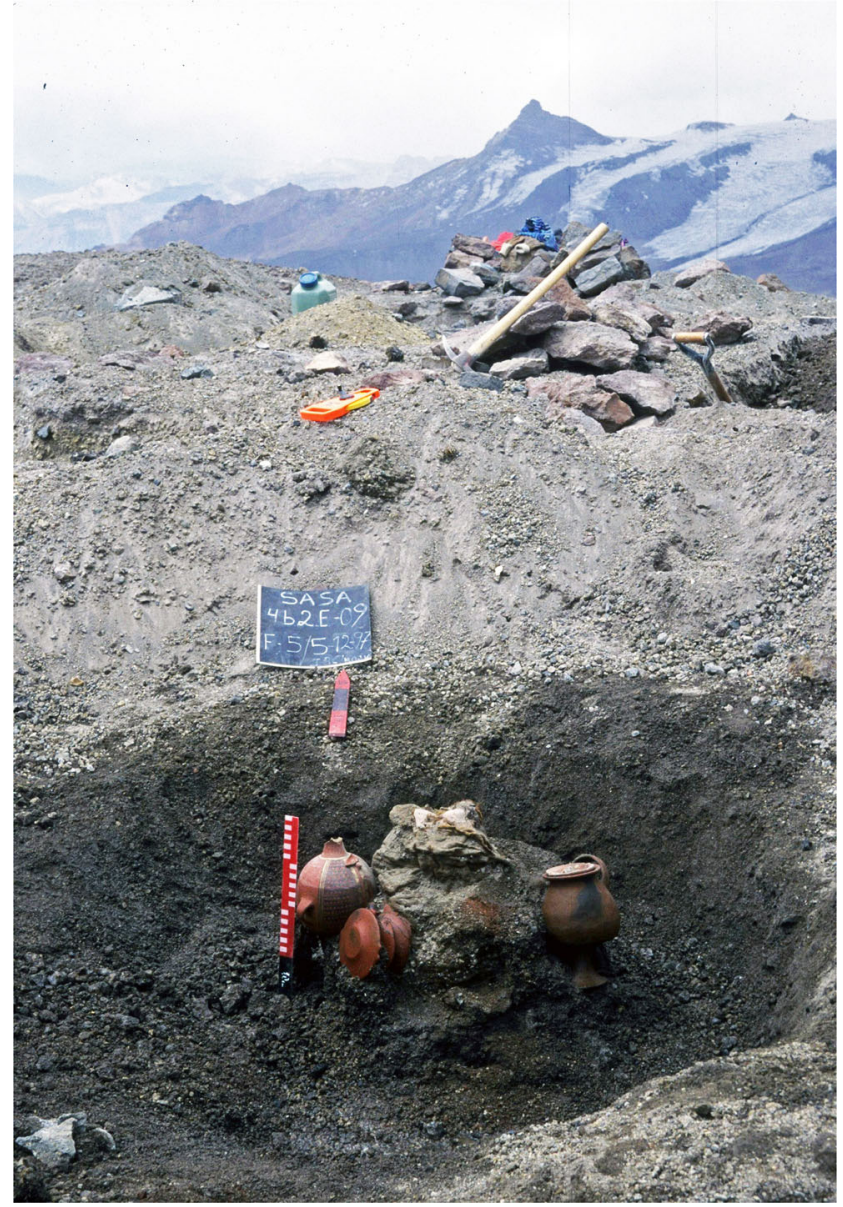

Fig. 4 Ampato \#4's burial during the excavation (photo Johan Reinhard) archaeologists excavated her along with the frozen soil and transported the body to the Andean Sanctuaries Museum (Museo Santuarios Andinos) in Arequipa. Because of the state of preservation, the block of soil first had to be unfrozen, and then the skeletal remains were cleaned of soil. The thawing process was done on special sieves to avoid the accumulation of water. The unstable environmental conditions on the Pichu Pichu summit had led to the full skeletonization of all the bodies found there.

The Ampato capacocha sacrifices were sacrificed at a higher altitude $(5800$ and $6300 \mathrm{~m}$ ) than those on Pichu Pichu. Additionally, the conditions before the eruption of Sabancaya in the early 1990s were more stable, and this led to better preservation of the bodies. The bodies of Ampato \#2 and \#4 were preserved in a mummified state and were still wrapped in textiles. The mummies were first cleaned of the remains of soil and ice. After the cleaning process, radiography was conducted to investigate the bodies without risk of damaging them. The skeletonization of Ampato \#3 was the result of a rise in soil temperature caused by multiple lightning strikes. The bones, textiles, and exposed skin surface of all individuals were examined with a mobile microscope.

The physical anthropological analyses focused on establishing age at the time of death and the presence of pathologies, traumas, and patterns of activity. The sex of the sacrificial victims was impossible to determine from only the bones (Schaefer et al. 2009). Nevertheless, the figurines and grave goods, such as tupus (female shawl pins), made it possible to preliminarily establish the sex of each victim.

The ages of the victims at the time of death were established based on tooth eruption, bone size, and state of fusion of the bones' epiphyses (Schaefer et al. 2009; Gaither 2004; Ubelaker 1979). Patterns of activity could be determined based on the development of entheses.

\section{Results}

\section{Age and sex}

Four of the five investigated individuals (Ampato \#2, \#3, and \#4 and Pichu Pichu \#1) were in the same age category of 6-7 years old. Age was estimated based on tooth eruption and bone measurements (Gaither 2004; Schaefer et al. 2009). The sole exception was Pichu Pichu \#2, who was sacrificed at age 3.5. This is the youngest capacocha sacrifice currently known.

The sex of all the individuals was hypothesized based on grave goods, such as tupus, and male and female figurines (Table 2). On Ampato, the capacocha sacrifices consisted of possible three females (Ampato \#1, \#2, and \#4) and one male (Ampato \#3). On Pichu Pichu, the sacrifices consisted of possible two females (Pichu Pichu \#1 and the body discovered in 1963) and one male (Pichu Pichu \#2). 


\section{Taphonomy and artefact associations}

The body of the Pichu Pichu \#1individual had been buried in a sitting position with her legs close to her chest. A gold tube was found placed on her forehead, which may have been part of a headdress whose organic parts have decomposed. Two silver $(12.6 \mathrm{~cm})$ and one gold $(9.2 \mathrm{~cm})$ tupus were found during the cleaning of the skeleton. The silver ones were located on the individual' shoulders. The gold tupu with two circular gold plates (4 $\mathrm{cm}$ diameter), eight Spondylus beads, two silver and one wooden bellshaped object, two copper needles, and cactus spines were found in the region of the chest. The silver bell-shaped items were plugged with copper.

The body of the individual Pichu Pichu \#2 was explored in situ. There were no remains of soft tissue or any associated objects except one male figurine and remains of chuspa bag. The individual had been buried in the sitting position.

The body of Ampato \#2 was preserved in a mummified state. The individual was in a sitting position similar to Pichu Pichu \#1. Ampato \#2 had been directly struck by lightning. The textiles on the skull were partially damaged, the soft tissue carbonized, and part of the right parietal bone had a white colour, suggesting that the temperature had been above $700^{\circ} \mathrm{C}$. This could have also led to the partial decomposition of the facial region. With radiography, it was possible to see three tupus inside the Ampato \#2 mummy bundle (Fig. 8). The green stains on the textile wrapping indicated that two of these were made from copper.

Similar evidence of lightning was visible on the bones of Ampato \#3. However, in this case, the lightning probably struck more than once. The high temperature led to the almost complete carbonization of the soft tissue and most of the organic materials. Fragments of two textiles (one red and the other decorated in yellow-black stripes) were still present. Based on white coloured areas, the left side of the parietal and occipital bone; the left scapula and clavicle; the lateral condyle of the right and left femur; the posterior part of T1, T2, T9, and T10; the third left-side rib; and the left foot bones all had traces of having been burned. The earth inside the burial pit was also partially vitrified.
The body of Ampato \#4 was also mummified. However, the upper part of the skull was partially skeletonized due to damage and exposure caused by external factors. The mummy was located above a stone box that contained a female figurine made from Spondylus shell and two miniature tupus. A similar box was found at the top of Pichu Pichu \#1's burial. This individual was buried in a sitting position with her legs close to her chest. The Ampato \#4 individual also wore three tupus inside its bundle (Fig. 9). A miniature wooden vase (kero) was found under the damaged textiles. This was similar to one discovered inside the Ampato \#2 burial.

\section{Body growth and patterns of activity}

It was possible to take direct bone measurements for three individuals (Ampato \#3, Pichu Pichu \#1 and \#2) due to their complete skeletonization. The results of measurements of the Ampato and Pichu Pichu individuals revealed that their bone sizes were much closer to modern European ones than preHispanic Andean ones (Table 1) (Drusini et al. 2001; Schaefer et al. 2009; Vega Dulanto 2009).

Pichu Pichu \#2 had well-marked muscle attachments in the region of the lower limbs. The posterior part of the femurs had developed in the area of the join with the biceps femoris muscle. Its function is twofold: it performs knee flexion and is a weaker hip extender when the knee is flexed, and it rotates the hip laterally. Due to the rapid remodelling rate of children's bones, it is possible that this attachment developed in the last months of this individual's life and was related to the pilgrimage from Cusco to Pichu Pichu as well as the effects of climbing in the mountains.

\section{Pathologies}

Few lesions were observed, and those that were found were mostly related to the first years of life. The neurocranial bones of the Ampato \#3 and Pichu Pichu \#2 individuals were asymmetrical. These changes could have been the result of malnutrition or a poorly balanced diet in the first month of life, but they could also be due to improper nursing. Placing an infant's
Table 1 The measurements of the long bones of Ampato \#3 and Pichu Pichu \#1 and \#2

\begin{tabular}{llll}
\hline & Ampato \#3 & Pichu Pichu \#1 & Pichu Pichu \#2 \\
\hline Age based on tooth eruption & 6 & $6-7$ & $3-4$ \\
Left femur & 275 & 267 & 194 \\
Left tibia & 229 & 215 & 156 \\
Left fibula & 220 & 213 & 155 \\
Right humerus & 186 & 200 & 146 \\
Right ulna & 161 & 159 & 121 \\
Right radius & 148 & 143 & 112 \\
\hline
\end{tabular}




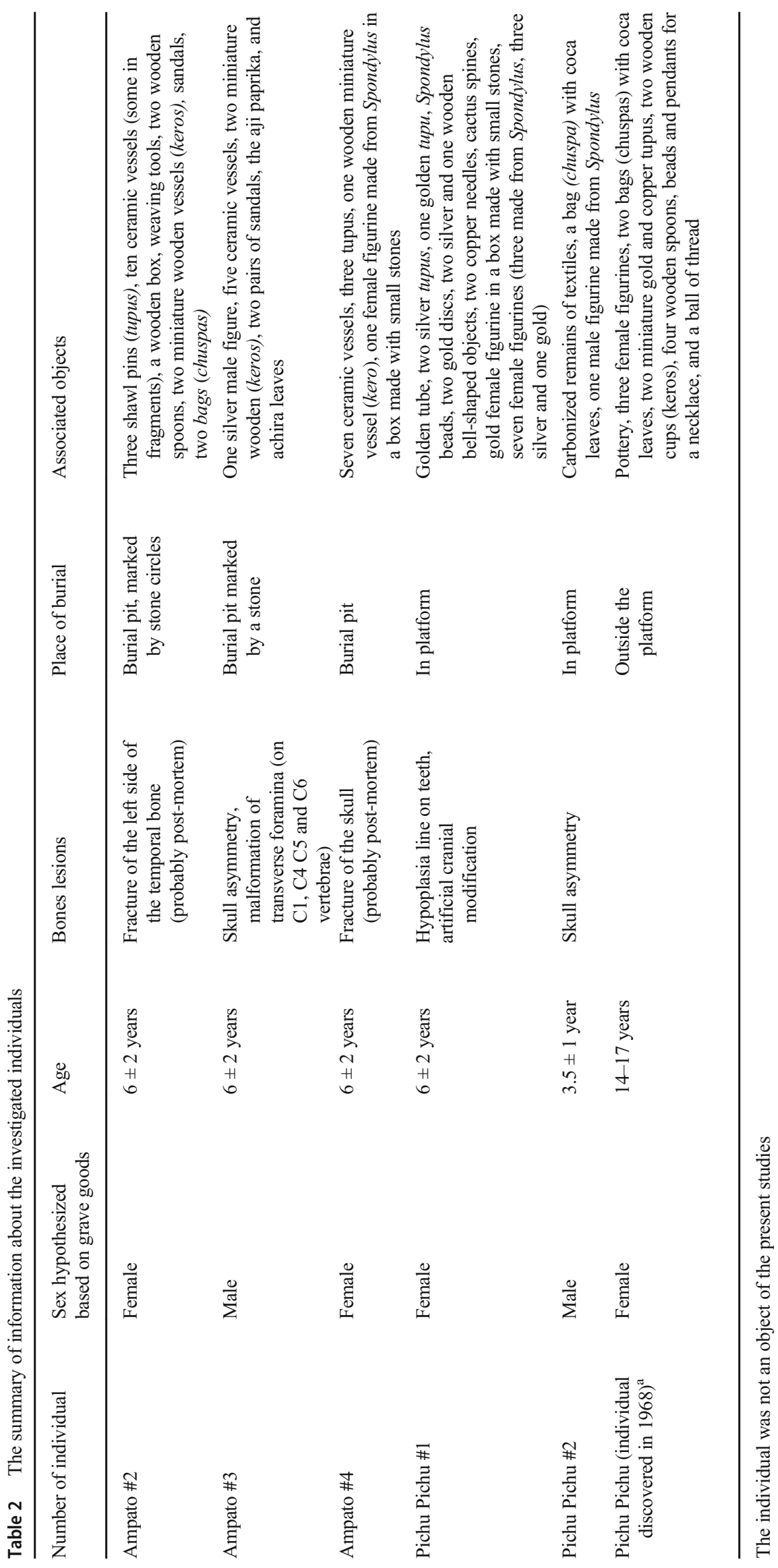


head in one position most of the time can lead to a flattening of the bones that are being pressed (Najarian 1999: 174-177).

Pathological lesions were observed in the cervical part of the spinal column of the Ampato \#3 individual (Fig. 6). The C1 vertebra's left transverse foramen was fused. In the lower part of the cervical vertebrae, the transverse foramina were divided in two at C4 (right), C5 (left), and C6 (both). The transverse foramina allow the passage of the vertebral artery and vein and the sympathetic nerve plexus. The double opening of the transverse foramen of the $\mathrm{C} 7$ vertebra appears in literature as an inheritable non-metric feature (Katzenberg and Saunders 2007: 536). The fusion of the foramen could be congenital and may have caused alterations in blood circulation and nerve damage (Cai et al. 2018; Goray et al. 2005; Aziz and Morgan 2018). The narrowing of the original path for the vessels and nerves could cause problems with blood circulation (thrombosis, emboli, reflex spasm) and partial paralysis. The correct and steady growth of the postcranial skeleton excludes the possibility of chronic paralysis. The lack of a natural path in the $\mathrm{C} 1$ foramen also exposes the vessels and nerves to possible damage (Sultana et al. 2015). The medical cases of patients who have fractured this region describe symptoms such as temporary blindness, blood circulation impairment, hypoxia, chronic headaches, vertigo, and loss of consciousness caused by abrupt movements of the head (Cai et al. 2018; Sultana et al. 2015).

Only one of the investigated individuals, Pichu Pichu \#1, had a dental growth disorder. A single hypoplasia line was visible on the teeth. It had started to form at around the age of 3 (Fig. 7). Hypoplasia is connected with malnutrition, hypocalcemia, fluoride ingestion, disease, and problems during pregnancy and birth, but it can also be caused by cultural stress. It has the form of multiple lines, plane surfaces, or pits (King et al. 2005). Pichu Pichu \#1 has only one line, which is unique. This suggests a singular stress event was responsible for its formation. Taking into account that the individual had the proper bone ossification rate and lacked porotic hyperostosis and cribra orbitalia, it must have been occurred over a short span of time. The most probable interpretation would be connected to cultural factors.

For the Pichu Pichu children and Ampato \#3, it was impossible to determine the cause of death. There was no blunt force trauma to the skull or changes in the region of the preserved hyoid bone or cervical vertebrae. However, strangulation does not always lead to bone fractures, and only Pichu Pichu \#1 still had a hyoid bone intact. Ampato \#4 does have a broken skull; the fracture probably occurred post-mortem since it is squared, with sharp edges at right angles to the bone surface (Kranioti 2015: 27). The bones were not covered by textiles, and the direction of pressure was inward. In other known examples, children were killed by a blow to the sides of the head, and on the hair of one individual, a dark substance was visible that could have been blood. The radiograph revealed that Ampato \#2 also had a break on the left side of the temporal bone. Since it was impossible to conduct tomography, it was impossible to determine if this had occurred perior post-mortem.

\section{Cultural attributes}

Only Pichu Pichu \#1 has an artificial cranial modification (Fig. 5). The individual's skull had been modified in a tabular oblique manner. Pressure was put on the frontal and occipital bones, which led to the elongation of the skull during infancy. Despite the significant increase in the length and surface area of the bones, there is no trace of disturbance to the density of bone. Porotic hyperostosis is often observed along cranial sutures as a response to forced changes in bone shape (Boston 2012:7). However, Pichu Pichu \#1 had the proper rate of ossification, which suggests good health and proper diet during early childhood.
Fig. 5 The skull of Pichu Pichu \#1, found on Pichu Pichu (photo Dagmara Socha)

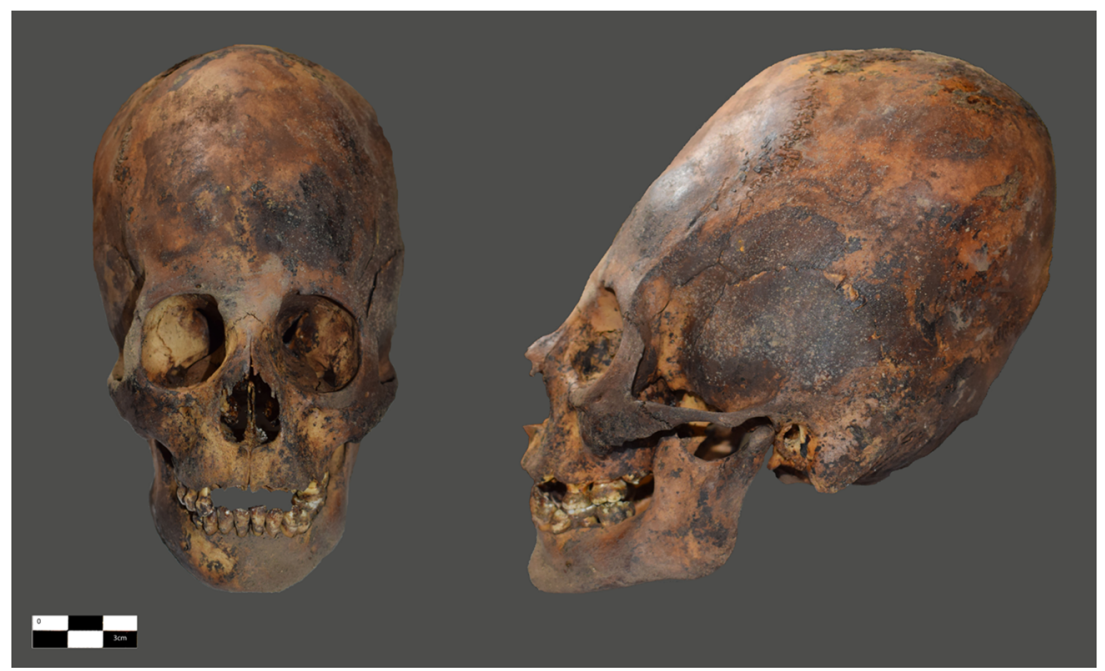


Fig. 6 The cervical vertebrae of Ampato \#3 (photo Dagmara Socha)

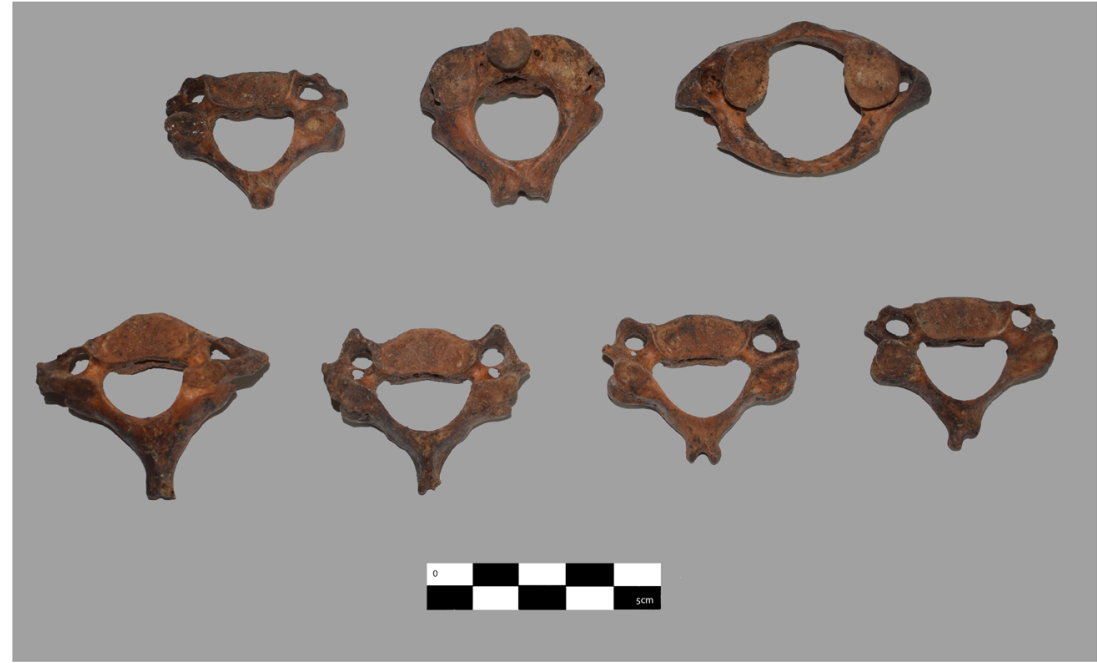

\section{Discussion}

The capacocha sacrifices from Pichu Pichu and the site on Ampato at $5800 \mathrm{~m}$ share a similar burial pattern to those found on Llullaillaco (Reinhard and Ceruti 2010), which were also three individuals, two females and one male. The silver bellshaped items found with Pichu Pichu \#1 individual were similar to those found with the Llullaillaco Maiden (Reinhard and Ceruti 2010: 82).

Previous interpretation of the sex and age of sacrifices has focused on the institution of sacred marriage as described by Juan Betanzos (1996 [1551-1557]: 77). He noted that younger individuals were supposed to be sacrificed in pairs. The older females were probably selected from the acllahuasi (Reinhard and Ceruti 2010:106).

The capacocha sacrifices from Pichu Pichu vary in their age categories as well as their possible social origins. The age difference between Pichu Pichu\#1 and \#2 is about three years. Pichu Pichu \#1 also has an artificial head modification, which suggests a different place of origin than that of the Pichu Pichu \#2 and the older (probable) female. The burial of the Pichu Pichu individual discovered in 1963 was located outside the main platform. This difference in burial placement could be the result of her subordinate role compared to the main capacocha sacrifices buried in the main part of the platform. Another explanation is that the Incas returned on separate occasions and performed at least two independent rituals on the summit.

At Ampato, all of the individuals buried at an altitude of $5800 \mathrm{~m}$ were of similar age. The older female (the Ampato Maiden) was likely sacrificed on the summit during an independent event. In previous studies of the Llullaillaco children, the Ampato Maiden, and the Sara Sara female, it was shown that the individuals were not related along maternal lines

Fig. 7 The hypoplasia line on the teeth of Pichu Pichu \#1 (photo Dagmara Socha)

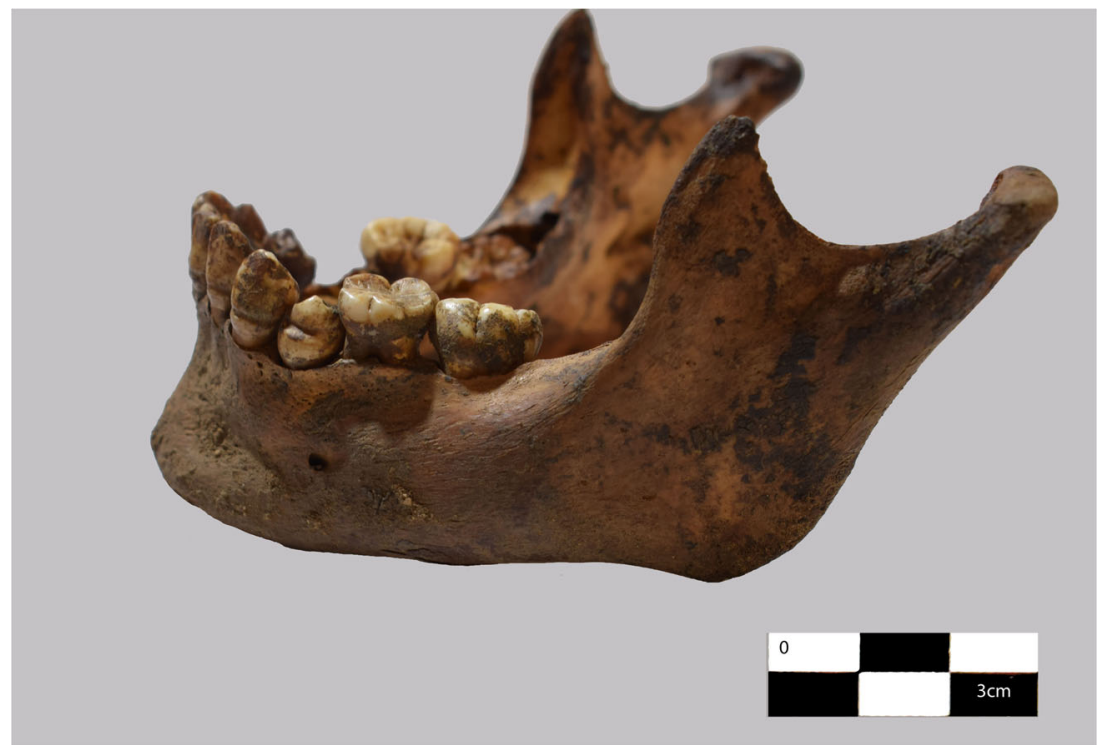


Fig. 8 The mummy of Ampato \#2 and her radiograph (photo Dagmara Socha)

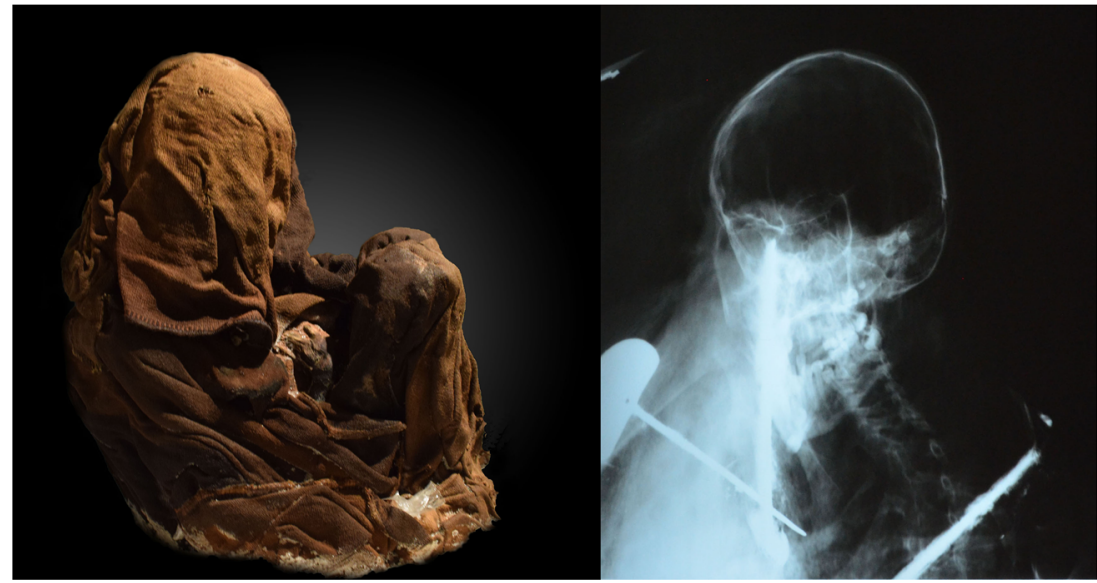

(Wilson et al. 2013). These results support the interpretation that the children were of different origins and that the Incas may have returned to sacrificial places on multiple occasions and not all of the individuals were buried during the same event.

The new studies on the capacocha sacrifices from Ampato, Pichu Pichu, and Misti (Socha et al. 2020) suggest that 5 to 7 years old was the most desirable age for victims. The chronicles do mention the Incas sacrificing breastfeeding infants (Cobo 1990 [1623]:112; Guaman Poma de Ayala 1980[1613]:245); however, this practice had not been confirmed in the archaeological record. Of the 28 capacocha individuals discovered on high mountains up until the present day, the majority (20) have been of a similar age category: 5-9 years old. The age of 5 was possibly a boundary, after which individuals were more likely to reach adolescence. The high juvenile morbidity in pre-Columbian Peru meant that many children did not reach this age (Drusini et al. 2001; Vega Dulanto 2009). The unusual young age of the Pichu Pichu \#2 could be due to a number of factors, such as his origin or a narrow time span in which to perform the capacocha (hence the lack of availability of a more suitable child). However, the reason for choosing such a young individual is still unclear.
The hypoplasia line on the teeth of Pichu Pichu \#1 could suggest that the children were housed for lengthy periods of time before the sacrifices were performed. The line appears around the third year of life. The stress could be the result of being separated from her parents after being chosen for sacrifice. This would explain the appearance of the singular line as well as the lack of other lesions related to disease or nutritional problems. However, this hypothesis requires more testing. Information about the duration of the capacocha ceremony appears in the chronicles of Hernández (1923 [1622]: 61-62). Tanta Carhua, who was volunteered by her parents for sacrifice, reportedly complained about the duration of the ritual.

The individuals from Pichu Pichu and the Ampato \#3 did not have any perimortem traumas. In two other cases (Ampato \#2 and \#4), it is impossible at this stage to determine if their injuries are taphonomic processes or not. A comparison of these bodies to other capacocha sacrifices supports the theory that the Incas desired the sacrifice of intact victims (Reinhard and Ceruti 2010: 125).

The bio-anthropological analysis of capacocha sacrifices reveals two coexisting descriptions that could be applied to the individuals selected for the ritual. On the one hand, all of the children were well-nourished, with thick layers of fat tissue in
Fig. 9 The mummy of Ampato \#4 and her radiograph (photo Dagmara Socha)

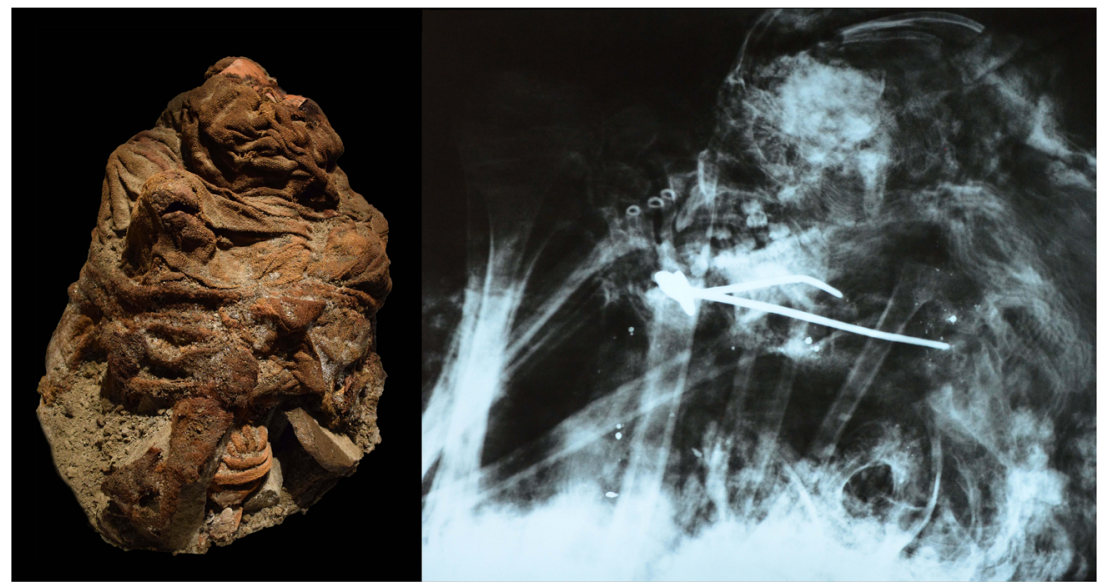


the case of the mummies and proper body growth (Previgliano et al. 2003: 1476). The chronicles mention food consumption as being an important aspect of the ritual - that is to say, only well-nourished children were sacrificed (Cobo 1990 [1623]: 112; Molina 1959 [1575]: 93). The research based on long bone measurements (Ampato \#3, Pichu Pichu \#1 and \#2) showed that the children selected as capacocha sacrifices had well developed postcranial skeletons compared to juveniles from common pre-Columbian cemeteries (Drusini et al. 2001; Vega Dulanto 2009). Studies of juveniles from the coast of Peru have shown great disproportion between teeth and postcranial development. An analysis of the population from a pre-Columbian cemetery showed that the infants and children there had slower postcranial skeleton growth compared to contemporary populations. This could be related to the minor impact of external factors on tooth growth, which makes them a better age marker. The proper body development of the capacocha children shows the impact of social status on the growth of juveniles: the bone measurements of the individuals in this study are closer to modern European standards (Schaefer et al. 2009). This leads to the conclusion that capacocha sacrifices did receive special treatment and thus supports the information in the chronicles about the elite origins of some of the children designated to be sacrificed.

On the other hand, some individuals were found to have lesions that could be interpreted as being due to congenital impairment. It was possible to trace this in an older individual from Misti with improper leg formation (Socha et al. 2020) and in the case of Ampato \#3. The malformation of the path for the vertebral artery and vein and the sympathetic nerve plexus could cause some serious medical issues (Cai et al. 2018; Goray et al. 2005; Aziz and Morgan 2018; Sultana et al. 2015). However, bone lesions alone are not enough to determine the health of an individual. Children with defects were often chosen for religious purposes in the ancient Andes. According to De Arriaga 1968[1621]: 214-215), people struck by lightning or those with some type of genetic abnormality such as curved legs or cleft lip were chosen to become priests of the god Illapa (the thunder and weather deity). A bone lesion that was an inherent malformation affecting the nervous and vascular system could also cause some kind of health condition that was desirable, as it was evidence of the interference of gods. However, taking into consideration the descriptions from the chronicles about the requirement for beauty and health in victims (Ramos Gavilán 1976 [1621]:56), the sacrifice of such individuals could also have been initiated for other reasons, like the urgent need for an offering (thus excluding the possibility of advanced selection) or an individual being volunteered by their parents in order to obtain special treatment from the Incas.

The capacochas fulfilled an important role in the Incas' provincial management strategy. The collection and preparation of sacrificial victims from different ethnic groups placed the state in the position of being the unique distributor of the most important offerings made in the Empire. The results of the studies of the Pichu Pichu and Ampato sacrifices confirmed the widespread origins, privileged positions, and high social status of the victims. The children were supposed to be in good general health and be aged around 5-9 years old. The studies show that the victims were well-nourished and had proper growth rate compared to juveniles from lower social strata. The connection between the high social status of the victims and the introduction of imperial gods and religious syncretism assisted in the subordination of conquered provinces.

Acknowledgements Dagmara Socha would like to acknowledge the Universidad Católica de Santa Maria in Arequipa for their financial support of this project and the director and staff of Museo Santuarios Andinos for their help and support while conducting the research. The research took place thanks to the cooperation between the Centre for Andean Studies, University of Warsaw and Universidad Católica de Santa María in Arequipa. Johan Reinhard would like to thank José Antonio Chávez, co-director of the Ampato and Pichu Pichu expeditions, the National Geographic Society for grants supporting the expeditions to Ampato and Pichu Pichu, and the Discovery TV for making the expedition to Pichu Pichu in 1996 possible.

Funding The project was financed by Universidad Católica de Santa Maria in Arequipa. During the works, the infrastructure of the Center for Andean Studies, University of Warsaw was used, financed by the Polish Ministry of Education and Science under the grant SPUB/SP/ 378784/2018.

Availability of data and materials All data and materials used in this article are available in the Museo Santuarios Andinos of Universidad Católica de Santa María in Arequipa.

\section{Declarations}

Conflicts of interest The authors declare no competing interests.

Open Access This article is licensed under a Creative Commons Attribution 4.0 International License, which permits use, sharing, adaptation, distribution and reproduction in any medium or format, as long as you give appropriate credit to the original author(s) and the source, provide a link to the Creative Commons licence, and indicate if changes were made. The images or other third party material in this article are included in the article's Creative Commons licence, unless indicated otherwise in a credit line to the material. If material is not included in the article's Creative Commons licence and your intended use is not permitted by statutory regulation or exceeds the permitted use, you will need to obtain permission directly from the copyright holder. To view a copy of this licence, visit http://creativecommons.org/licenses/by/4.0/.

\section{References}

Acosta J (1962) [1590] Historia Natural y Moral de las Indias, 2nd edn. Fondo de Cultura Económica, México

Andrushko VA, Verano JW (2008) Prehistoric trepanation in the Cuzco region of Peru: a view into an ancient Andean practice. Am J Phys Anthropol 137(1):4-13. https://doi.org/10.1002/ajpa.20836 
Andrushko VA, Buzon MR, Gibaja AM, McEwan GF, Simonetti A, Creaser RA (2011) Investigating a child sacrifice event from the Inca heartland. J Archaeol Sci 38(2):323-333. https://doi.org/10. 1016/J.JAS.2010.09.009

Aziz J, Morgan M (2018) Morphological study of the foramen transversarium of the atlas vertebra among Egyptian population and its clinical significance. Anat Physio Biochem Int J 4(4):163167. https://doi.org/10.19080/APBIJ.2018.04.555642

Bárcena R (1989) Pigmentos en el Ritual Funerario de la Momia del Cerro Aconcagua. Xama 2:61-116

Beorchia A (1985) El Enigma de los Santuarios Indígenas de Alta Montaña. Revista del Centro de Investigaciones Arqueológicas de Alta Montaña 5.

Besom T (2009) Of summits and sacrifice: an ethnohistoric study of Inka religious practices. University of Texas Press, Austin

Betanzos J (1996 [1551-1557]) Narratives of the Incas. University of Texas Press, Austin

Boston E (2012) Investigations of the biological consequences and cultural Motivations of artificial cranial modification among Northern Chilean populations (Unpublished doctoral dissertation). University of Western Ontario, Ontario

Bray TL, Minc LD, Ceruti MC, Chávez JA, Perea R, Reinhard J (2005) A compositional analysis of pottery vessels associated with the Inca ritual of capacocha. J Anthropol Archaeol 24(1):82-100. https://doi. org/10.1016/J.JAA.2004.11.001

Cai D, Roach R, Weaver J, McGillicuddy G, Mansell Z, Eskander J, Eskander M (2018) Bow hunter's syndrome in a patient with a right hypoplastic vertebral artery and a dynamically compressible left vertebral artery. Asian Journal of Neurosurgery 13(1):133-135. https://doi.org/10.4103/1793-5482.181129

Ceruti MC (2015) Frozen mummies from Andean mountaintop shrines: Bioarchaeology and ethnohistory of Inca human sacrifice. BioMed Research International. https://doi.org/10.1155/2015/439428

Checura J (1977) Funebria incaica en el cerro Esmeralda (Iquique, I región). Estudios Atacameños Arqueología y Antropología Surandinas 5:127144. https://doi.org/10.22199/S07181043.1977.0005.00009

Cieza de León P (1959[1553]) The Incas of Pedro Cieza de León. Victor Wolfgang Von Hagen (ed.). University of Oklahoma Press, Norman.

Cobo B (1990 [1623]) Inca religion and customs. R. Hamilton (tr. and ed.). University of Texas Press, Austin.

Corthals A, Koller A, Martin DW, Rieger R, Chen EI, Bernaski M, Recagno G, Dávalos LM (2012) Detecting the immune system response of a 500 year-old Inca mummy. PLoS One 7(7):e41244. https://doi.org/10.1371/journal.pone.0041244

De Arriaga PJ (1968[1621]) La extirpación de la idolatría en el Pirú. Biblioteca de Autores Españoles, Madrid

Dorsey G (1901) Archaeological investigations on the Island of La Plata, Ecuador. Field Columbian Museum, Anthropol Series 56:2 (5)

Drusini AG, Carrara N, Orefici G, Rippa BM (2001) Palaeodemography of the Nasca valley: reconstruction of the human ecology in the southern Peruvian coast. HOMO 52(2):157-172. https://doi.org/ 10.1078/0018-442X-00026

Gaither C (2004) Growth and development studies of coastal prehistoric Peruvian populations (doctoral dissertation). Tulane University, New Orlean. Proquest 3170323.

Goray VB, Joshi AR, Garg A, Merchant S, Yadav B, Maheshwari P (2005) Aortic arch variation: a unique case with anomalous origin of both vertebral arteries as additional branches of the aortic arch distal to left subclavian artery. Am J Neuroradiol 26(1):93-95

Guaman Poma de Ayala F (1980[1613]) El primer Nueva crónica y buen gobierno. Siglo Veintiuno, Mexico

Hernández P (1923[1622]) Mitología andina. Revista Inca 1(1):25-78

Katzenberg MA, Saunders SR (eds) (2007) Biological anthropology of the human skeleton (2nd ed). John Wiley \& Sons, New Jersey

King T, Humphrey LT, Hillson S (2005) Linear enamel hypoplasias as indicators of systemic physiological stress: evidence from two known age-at-death and sex populations from postmedieval London. Am J Phys Anthropol 128(3):547-559. https://doi.org/10. 1002/ajpa.20232

Kranioti E (2015) Forensic investigation of cranial injuries due to blunt force trauma: current best practice. Res Rep Forensic Med Sci 5:2537. https://doi.org/10.2147/RRFMS.S70423

Linares E (1966) Restos arqueológicos en el nevado de Pichu Pichu (Arequipa, Peru). Anales de Arqueología y Etnología 21:7-47

Malpass M, Alconini S (eds) (2010) Distant provinces in the Inka Empire: toward a deeper understanding of Inka imperialism. University of Iowa Press, Iowa City

Meindl RS, Lovejoy CO (1985) Ectocranial suture closure: a revised method for the determination of skeletal age at death based on the lateral-anterior sutures. Am J Phys Anthropol 68(1):57-66. https:// doi.org/10.1002/ajpa.1330680106

Meinken AK (2005) Trabajos arqueológicos en las kallankas de los sitios Ccopan, La Joya y Acchaymarca, temporada 2004. M Ziółkowski, M Sobczyk (Eds.) Andes. Proyecto Arqueológico Condesuyos 6:65-92

Molina C (1959[1575]) Ritos y Fábulas de los Incas. Editorial Futuro, Buenos Aires.

Murúa M (1946[1590]) Historia general del Perú. Ediciones Historia, Madrid.

Najarian SP (1999) Infant cranial molding deformation and sleep position: implications for primary care. J Pediatr Health Care 13(4): 173-177. https://doi.org/10.1016/S0891-5245(99)90036-6

Ondegardo P (1917[1571]) Informaciones Acerca de la Religión y Gobierno de los Incas. Sanmarti y Ca, Lima

Previgliano CH, Ceruti C, Reinhard J, Araoz FA, Diez JG (2003) Radiologic evaluation of the Llullaillaco Mummies. Am J Roentgenol 181(6):14731479. https://doi.org/10.2214/ajr.181.6.1811473

Prieto G, Verano JW, Goepfert N, Kennett D, Quilter J, Leblanc S, Fehren-Schmitz L, Forst J, Lund M, Dement B, Dufour E, Tombret O, Calmon M, Gadison D, Tschinkel K (2019) A mass sacrifice of children and camelids at the Huanchaquito-Las Llamas site, Moche Valley, Peru. PLoS One 14(3):e0211691. https://doi. org/10.1371/journal.pone.0211691

Prunes L (1957) Estudio médico. In: La Momia del Cerro el Plomo. Boletín del Museo Nacional de Historia Natural de Chile 19

Quevedo S, Durán E (1992) Ofrendas a los dioses en las montañas: Santuarios de altura en la cultura Inka. Boletín del Museo Nacional de Historia Natural de Chile 43:193-206

Ramos Gavilán A (1976[1621]) Historia de Nuestra Señora de Copacabana. Editorial Universo, La Paz

Reinhard J (2006) The Ice Maiden: Inca mummies, mountain gods, and sacred sites in the Andes. National Geographic Books, Washington

Reinhard J, Ceruti C (2010) Inca rituals and sacred mountains: a study of the world's highest archaeological sites. University of California, Los Angeles

Rescaniere AO (1986) Imperfecciones, demonios y héroes andinos. Anthropologica del Departamento de Ciencias Sociales 4(4):191-224

Sanhueza SA, Pérez ML, Díaz JJ, Busel MD, Castro M, Pierola TA (2005) Paleoradiologia: estudio imagenologico del niño del cerro el Plomo. Rev Chil Radiol 11(4):184-190. https://doi.org/10.4067/ S0717-93082005000400007

Schaefer M, Black S, Scheuer L (2009) Juvenile osteology: a laboratory and field manual. Elsevier Academic Press, London. https://doi.org/ 10.1016/B978-0-12-374635-1.X0001-X

Schobinger J (2001) El santuario incaico del cerro Aconcagua, 1st edn. Editorial de la Universidad Nacional de Cuyo, Mendoza

Schobinger J (2003) La momia Inca del Nevado de Chuscha (noroeste Argentino): Resultado preliminar de su estudio. Boletín de Arqueología PUCP 7:277-285

Sikkink L (1997) Water and exchange: the ritual of yaku cambio as communal and competitive encounter. Am Ethnol 24(1):170-189

Socha DM, Reinhard J, Chávez Perea R. (2020) Inca human sacrifices on Misti volcano (Peru). Latin American Antiquity (in press). 
Sultana QX, Avadhani A, Varalakshmi KL, Shariff MH (2015) Variations of foramen transversarium in atlas vertebrae: a morphological study with its clinical significance. $J$ Health Allied Sci NU $5(2): 80-83$

Ubelaker D (1979) Human skeletal remains: excavation, analysis and interpretation. Smithsonian Institute Press, Washington

Vega Dulanto MC (2009) Estimación de edad en subadultos: estudio dental y métrico en poblaciones andinas peruanas (unpublished master tesis). PUCP, Lima
Wilson AS, Brown EL, Villa C, Lynnerup N, Healey A, Ceruti MC, Reinhard J, Previgliano CH, Araoz FA, Gonzalez Diez J, Taylor T (2013) Archaeological, radiological, and biological evidence offer insight into Inca child sacrifice. Proc Natl Acad Sci 110(33):1332213327. https://doi.org/10.1073/pnas.1305117110

Publisher's note Springer Nature remains neutral with regard to jurisdictional claims in published maps and institutional affiliations. 